ECONOMIC THEMES (2020) 58(1): 53-73

S sciendo

DOI 10.2478/ethemes-2020-0004

\title{
MONETARY POLICY TRANSMISSION ON REAL TRENDS IN SERBIA - VAR ANALYSIS
}

\author{
Jelena Obradović \\ Novi Sad School of Business \\ PhD student, Faculty of Economics, University of Niš, Republic of Serbia \\ $\bowtie$ jelena.obradovic.vps@gmail.com
}

Marina Đorđević

Faculty of Economics, University of Niš, Republic of Serbia

$\triangle$ marina.djordjevic@eknfak.ni.ac.rs

UDC

338.23:336.

74]:31

Original scientific paper

Received:

07.02.2020

Accepted:

28.02.2020
Abstract: The efficiency of channels of monetary transmission varies from country to country and is conditioned by a number of factors that determine the economic and financial system of a country. In order to achieve the set monetary policy objectives, a central bank takes certain measures and employs instruments of monetary policy. Those instruments, however, act indirectly and with a certain lag. Due to these limitations in monetary policy effects, the analysis of the monetary transmission is of essence in every country as it enables its designers to determine an optimum monetary regime. In this paper, an analysis of monetary transmission in the Republic of Serbia is made using the Vector autoregressive model (VAR model). The research conducted is significant due to a current issue of the impact of monetary policy on actual economic trends, both in the developed and developing countries. On the basis of the research it is concluded that, in the time period under observation, the biggest impact on the fluctuations in industrial production in Serbia is that of monetary aggregate, whereas the biggest impact on the fluctuation in prices is that of key policy rate movements. The results of the analysis provide guidelines to monetary authorities to take necessary steps to shorten a lag period and eliminate restrictions in transmitting monetary impulses into real economic values.

Keywords: transmission mechanism of monetary policy, interest rate, CPI, exchange rate, industrial production, M1, oil price, VAR model

JEL classification: E52, C50 


\section{Introduction}

In discharging their core duties, central banks contribute to a well-being of an entire economy. One of their primary functions is pursuance of monetary policy through which they have an impact on both the economic and population sectors. This process takes place through the channels of monetary transmission. „The issue of the effects of monetary policy on prices and real economic activity lies at the core of macroeconomic theory and at the heart of monetary policy" (Robinson \& Robinson, 1997, p. 3). Žigman and Lovrinčević (2005) point out that the importance of certain channels of monetary transmission differs from country to country, depending on the level of development of the financial system and institutional framework. „The monetary transmission mechanism is the process through which monetary policy decisions are transmitted into changes in real GDP and inflation" (Taylor, 1995, p. 11). By analysing the transmission mechanism of monetary policy in a certain country, monetary authorities take concrete actions to make an impact on real economic trends.

Every monetary strategy has certain advantages and downsides. Under modernlife circumstances, a great number of countries have chosen the strategy of inflation targeting due to its manifold positive macroeconomic effects and this is also the case in Serbia. The 2006 National Bank of Serbia Memorandum sets a new framework of monetary policy directing it towards the control of inflation rate measured by the consumer price index (CPI). The new monetary policy strategy in Serbia proved to be successful in reducing the inflation rate on the short run, although it was not always within the targeted range. That was, among other things, due to an increase in the inflationary expectations as a result of the global financial crisis at the inception of the new regime. Changes in food prices significantly contributed to the inflation rate level movements. "In addition to that, as Serbia is a highly eurized and import-dependent country, exchange rate movements had a great effect on the inflationary expectations" (Bungin, 2006, p. 142). The National Bank of Serbia was frequently forced to intervene on the foreign exchange market in order to preserve the value of the domestic currency under conditions of high volatility of exchange rate. In addition to that, a low aggregate demand, coupled with other factors, contributed to the inflation rate which was frequently below the targeted range in the past few years.

\section{Literature review}

„For good policy-making, it is necessary to measure how monetary policy is affected by different macroeconomic conditions and how it affects the macroeconomy" (Berument \& Dincer, 2008, p. 83). Đorđević (2005) points out that the response of an economy to a monetary shock also depends on the fact whether a monetarypolitical action is expected or not and whether an exogenous shock or the change is 
a result of a political rule. For the purpose of an empirical analysis of the impact of monetary policy on real economic trends, the Vector autoregressive model (VAR model) is used in this paper. This model is applied in a great number of papers dealing with the impact of monetary policy on the economy in numerous countries worldwide. „The main problem when evaluating the effects of monetary policy empirically lies in identifying the monetary policy shocks" (Barran et al., 1996, p. 13).

"These methods generally deliver empirically plausible assessments of the dynamic responses of key macroeconomic variables to monetary policy innovations" (Bernanke et al., 2004, p. 1). Bernanke and Mihov (1995) make the same conclusion, pointing out that VAR-based methods are a promising approach in measuring monetary policy effects. It is also important to emphasise that macroeconomic variables, such as production and inflation rate, do not change immediately and simultaneously under the impact of economic shocks, whereas monetary policy makers may respond immediately to macroeconomic changes (Bjørnland, 2008, p. 200).

The Vector autoregressive model (VAR model) was introduced by Christopher A. Sims (1980), to observe the effects of monetary policy shocks in several countries. By comparing the results, he pointed out similarities and differences between the countries. The analysis of differences in the monetary policy transmission mechanism between countries particularly gained in importance with the establishment of the European Monetary Union (EMU). The reason for that is the fact that attempts are being made to narrow such differences if there are currency unions. Sims spotted significant differences between the structural characteristics of the countries under observation, even between those within the EMU. „Understanding how structural differences affect economies' responses to monetary policy is especially relevant in the context of prospective currency unions, but is also of great importance for monetary economics and policy in general" (Jarociński, 2008, p. 7).

Bernanke and Gertler (1995) observe, by means of the VAR model, that when an economy's response to monetary policy shocks is concerned, there are predominantly assertions that monetary tightening in the short run results in a continuous drop in both output and prices, and that a drop in aggregate demand leads to a drop in production. In addition to that, they concluded that investment in property is an aggregate demand component that, along with consumer goods consumption, responds faster than other components to deterioration in financial conditions.

Although it is known that monetary policy is an efficient tool of macroeconomic policy, this assertion depends on certain assumptions. Arestis and Sawyer (2002) state that one of the assumptions is that changes in interest rate significantly affect the level of aggregate demand and inflation rate. Angeloni et al. (2002, p. 21), by using the VAR model, make a conclusion that "in the euro-zone there are significant and acceptable effects of monetary policy on output and prices". They observe that 
unexpected rise in short-term interest rate has as an effect on a temporary reduction in output, whereby the strongest effect is felt after one year, whereas prices change at a slower pace and are reduced in the period following the first year.

By using the VAR model in their work, Peersman and Smets (2001) conducted an analysis of monetary transmission in the EU-15. They made a conclusion that an increase in short-term interest rate results in the fall in GDP and price level, whereby prices responded a few quarters following the GDP response. The fall in GDP was predominantly a consequence of a reduction in investments. Besides, there was an appreciation in the exchange rate. Similar results were also obtained by Mojon and Peersman (2001) who conducted an analysis on an example of a few countries within the EU-15 and proved that the monetary shock first had an impact on a temporary reduction in GDP (mostly due to a change in the level of investments and export), and after that on a reduction in price level.

Van Els et al. (2001), using the VAR model in the analysis of the transmission of monetary policy in the eurozone, also came to a conclusion that an increase in short-term interest rates affects faster the output than prices. Besides, they realised that in the first two years the exchange rate channel was dominant and subsequently the interest rate channel.

Vizek (2007) points out that, unlike the EU-15 countries, there was no significant interest in the analysis of the transmission of monetary policy in the countries of Central and Eastern Europe in the period in which the previously mentioned studies took place. When some countries of this region joined the European Union, a greater interest was shown for them. Besides, until few years ago, there was a lesser interest in the analysis of monetary transmission in all developing countries and fewer studies were conducted in that sphere. Studies conducted on the example of those countries in the past few years mainly led to a conclusion that the exchange rate channel dominated such economies and that it was followed by the credit channel.

When more recent studies are concerned, Yushina (2019) proved, by using the VAR model, that the interest rate channel was dominant in Russia and that central bank can have a significant impact on GDP through interest rate. Anant and Kaur (2017) also used the VAR model in the analysis of the transmission mechanism of monetary policy and presence of interest rate channel in India. They reached a conclusion that "the transmission of interest rates pass-through from policy rates to market interest rates (both - short-term as well as long-term) has strengthened while desired impact of long term market interest rates on industrial production and inflation appears to be weak" (Anant \& Kaur, 2017, p. 1).

Although the VAR model is useful in the research of this kind, several of its downsides are mentioned in theory. This model is criticised for comprising relatively few information relating to a relationship between variables which would be useful in model specification. Furthermore, it can be questioned if the selected order of models is appropriate or not and in what way the corresponding number of lags could 
be defined. The more variables the greater number of estimated parameters. Another VAR model downside relates to a dilemma if all components comprised by the model should be stationary.

\section{Methodology}

Dabla-Norris and Floerkemeier (2006) state that the VAR model is presented by the following equation:

$$
\mathrm{Y}_{\mathrm{t}}=\mathrm{A}(\mathrm{L}) \mathrm{Y}_{\mathrm{t}-1}+\mathrm{B}(\mathrm{L}) \mathrm{X}_{\mathrm{t}}+\varepsilon_{\mathrm{t}}(1)
$$

In this equation, $Y_{t}$ represents the vector of endogenous variables, $X_{t}$ expresses the vector of exogenous variables, $\varepsilon_{t}$ represents the vector of random errors, whereas $\mathrm{A}(\mathrm{L})$ and $\mathrm{B}(\mathrm{L})$ are matrices of lag operators. The vector of endogenous variables in this research comprises industrial production $\left(y_{t}\right)$, consumer price index - CPI $\left(p_{t}\right)$, key policy rate $\left(s_{t}\right)$ and nominal exchange rate $\left(x_{t}\right)$, which makes the first model:

$$
Y_{t}=\left[y_{t}, p_{t}, s_{t}, x_{t}\right](2)
$$

The order of the stated variables is not random and it is set by observing their mutual impact. In the second variant, the model is extended by adding monetary aggregate M1 $\left(m_{t}\right)$. In the specification this variable comes after the key policy rate and prior to the exchange rate, which is as follows:

$$
Y_{t}=\left[y_{t}, p_{t}, s_{t}, m_{t}, x_{t}\right] \text { (3) }
$$

The primary assumption of the model is that in the short run changes in other variables do not affect simultaneously the output and prices. This is due to a slower response of the real sector to monetary shocks and exchange rate changes. While interest rate, on the one hand, responds simultaneously to changes in production and prices, this is, on the other hand, not the case with the changes in financial variables. Monetary aggregates are affected by changes in output, prices and monetary policy, whereas the nominal exchange rate is affected by all shocks. The vector of exogenous variables $\left(X_{t}\right)$ in this research comprises the index of world oil prices $\left(\right.$ oilp $\left._{t}\right)$ and $\mathrm{EU}$ interest rate $\left(s_{t}^{E U}\right)$, and it is as follows:

$$
X_{t}=\left[\text { oilpt }_{t} s_{t}^{E U}\right] \text { (4) }
$$

Next, the analysis of the transmission mechanism of monetary policy in the Republic of Serbia is presented. Monthly data from January 2010 through April 2017 are used in the analysis. Within the mentioned model variables, instead of the gross domestic product (GDP) value, the value of industrial production calculated on a monthly based is used.

This analysis comprises several data processing stages. Stage 1 implies a descriptive analysis of the original time series and also includes a descriptive statistics of macroeconomic variables and a correlation matrix for all variables 
included in the modelling. Stage 2 implies determining the stationarity of time series by unit root testing using the ADF (Augmented Dickie Fuller) test. A necessary requirement for time series to be modelled into the VAR model is that they are stationary. In certain cases, if time series is not stationary, the analysis implies time series differentiation (first difference) in order to obtain a stationary time series. Following the differentiation, the time series is tested again using the ADF test in order to confirm the stationarity.

Stage 3 implies conceiving the VAR model by including macroeconomic variables, testing the lag order in VAR model specification by applying different selection criteria: Sequential modified LR test statistic (LR), Final prediction error (FPE), Akaike information criterion (AIC), Schwarz information criterion (SC) and Hannan-Quinn information criterion (HQ). In addition to that, VAR model coefficients are calculated and presented in order to determine the short-term tual causality between macroeconomic variables. It should be mentioned here that it is not possible to determine causalities between macroecnomic variables in the long run due to the quality of time series. Namely, the greatest number of the original (non-modified) time series is stationary and it is not possible to specify the Vector error correction model (VECM) which could indicate causality in the long run as for this type of analysis it is necessary to have non-stationary time series.

Stage 4 involves VAR model residual testing with CPI, exchange rate and industrial production as dependent variables. The residual analysis comprises descriptive observation, the analysis of autocorrelation function, autocorrelation testing using the correlation Portmanteau test which is based on the null hypothesis testing that there is no autocorrelation residual up to the maximum 12 lag periods.0 In addition to that, residual testing comprises the residual normality test by applying the Cholesky (Lutkepohl) as an orthogonalization method. The normality test is used to test the null hypothesis relating to residuals multivariate normal distribution.

Stage 5 of the empirical analysis implies variance decomposition (by applying Monte Carlo simulation with 10000 replications) of dependent variables (CPI, exchange rate and industrial production) in order to determine to which extent macroeconomic variables explain variation percentage of dependent variables. The final part of the analysis comprises the assessment of impulse response functions, whereby the impact of change (innovation) of macroeconomic variables on dependent variables is measured.

\section{Results and discussion}

The descriptive presentation of the original time series (CPI, exchange rate, monetary aggregate M1, industrial production, key policy rate, EU interest rate and oil price), used in our analysis for Serbia is given in Figure 1. 
Figure 1. Descriptive presentation of the original time series for Serbia

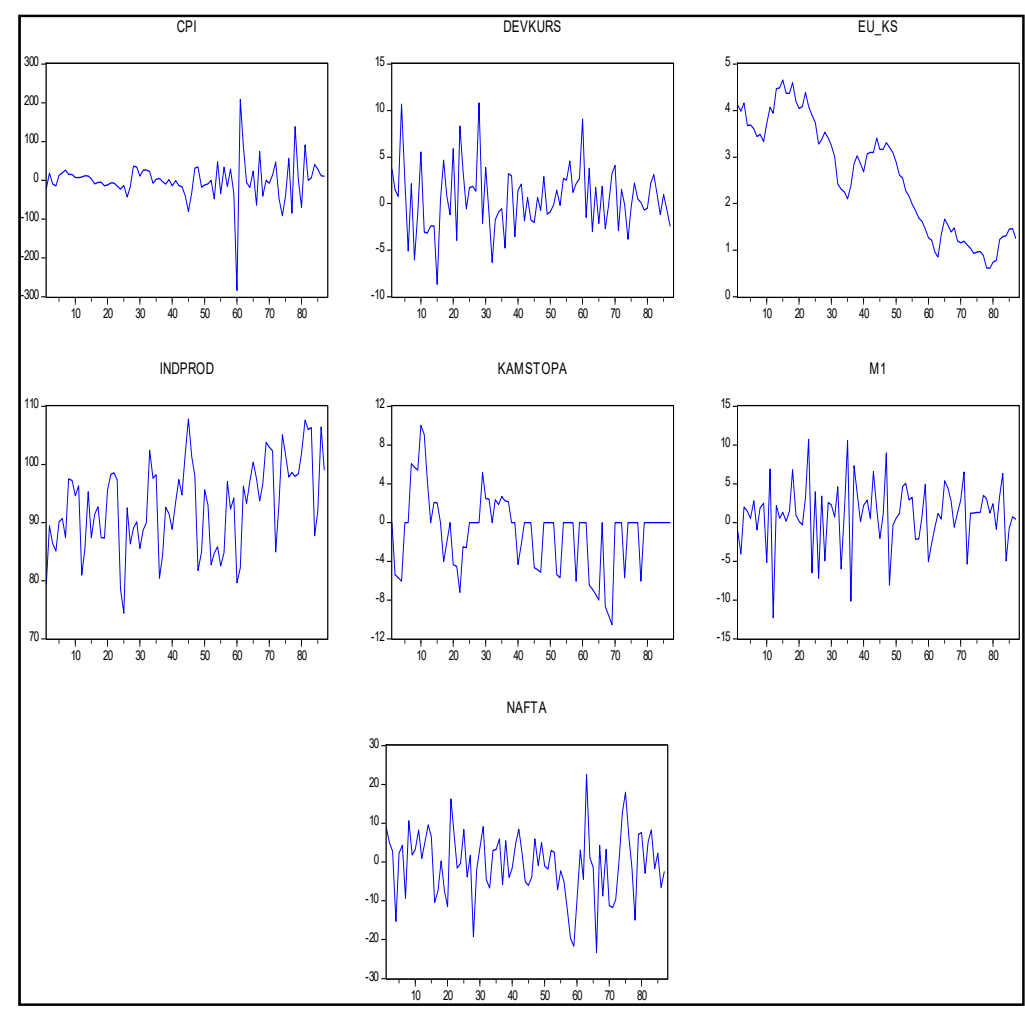

Source: Authors

Descriptive analysis of time series shows that M1 and oil price are approximately symmetrically distributed around the central tendency. CPI is pronouncedly oscillatory in the last quarter of the period under observation, while exchange rate has asymmetric oscillations during the whole period. Asymmetric oscillations are also present in national interest rate, industrial production and EU interest rate. With the exception of the traditionally unstable oil price, there is a pronounced instability of CPI and a significant instability of industrial production which is indicated by the standard deviation (Table 1).

The matrix of macroeconomic variables correlation (Table 2) indicates that there is a stronger positive correlation between industrial production and M1, as well as between national interest rate and EU interest rate. There is also a stronger negative correlation between exchange rate and oil price. 
Table 1. Descriptive statistics of macroeconomic variables

\begin{tabular}{|c|c|c|c|c|c|c|c||}
\hline & CPI & ER & EU IR & IP & IR & M1 & OIL \\
\hline Mean & -0.20957 & 0.543651 & 2.586092 & 92.95057 & -0.99425 & 1.030824 & -0.44876 \\
\hline Median & 0 & 0.467186 & 2.86 & 93.4 & 0 & 1.233148 & 0.385929 \\
\hline Maximum & 207.9442 & 10.83609 & 4.66 & 107.8 & 10.00835 & 10.73851 & 22.5326 \\
\hline Minimum & -283.321 & -8.67199 & 0.61 & 74.4 & -10.5361 & -12.3186 & -23.2774 \\
\hline Std. dev. & 52.42887 & 3.419765 & 1.217741 & 7.564849 & 3.828177 & 4.113122 & 8.524399 \\
\hline Skewness & -0.92958 & 0.457752 & -0.02967 & -0.12277 & -0.07952 & -0.57953 & -0.31479 \\
\hline Kurtosis & 14.1556 & 4.228736 & 1.635919 & 2.364964 & 3.546498 & 4.201917 & 3.428471 \\
\hline Jarque-Bera & 463.6514 & 8.511289 & 6.757856 & 1.680395 & 1.174334 & 10.10658 & 2.102386 \\
\hline Probability & 0 & 0.014184 & 0.034084 & 0.431625 & 0.5559 & 0.006388 & 0.349521 \\
\hline Sum & -18.2322 & 47.29765 & 224.99 & 8086.7 & -86.4997 & 89.68172 & -39.0419 \\
\hline Sum Sq.Dev. & 236395.6 & 1005.752 & 127.5289 & 4921.517 & 1260.325 & 1454.928 & 6249.223 \\
\hline Opservations & 87 & 87 & 87 & 87 & 87 & 87 & 87 \\
\hline \hline
\end{tabular}

Source: Authors' calculation

Table 2. Matrix of macroeconomic variables correlation

\begin{tabular}{||c|c|c|c|c|c|c|c||}
\hline & CPI & ER & EU IR & IP & IR & M1 & OIL \\
\hline CPI & 1 & -0.15835 & -0.04876 & -0.01461 & 0.014437 & -0.01622 & 0.017984 \\
\hline ER & -0.15835 & 1 & 0.007573 & -0.13474 & -0.18142 & -0.04747 & -0.39931 \\
\hline EU IR & -0.04876 & 0.007573 & 1 & -0.37841 & 0.204175 & -0.02386 & 0.110637 \\
\hline IP & -0.01461 & -0.13474 & -0.37841 & 1 & -0.11482 & 0.298257 & 0.02249 \\
\hline IR & 0.014437 & -0.18142 & 0.204175 & -0.11482 & 1 & -0.12684 & 0.079448 \\
\hline M1 & -0.01622 & -0.04747 & -0.02386 & 0.298257 & -0.12684 & 1 & 0.083875 \\
\hline OIL & 0.017984 & -0.39931 & 0.110637 & 0.02249 & 0.079448 & 0.083875 & 1 \\
\hline \hline
\end{tabular}

Source: Authors' calculation

$A D F$ test for unit root (Table 3) shows that EU interest rate and industrial production are non-stationary, whereas other original time series are stationary. After time series differentiation, the ADF test shows that the EU interest rate and industrial production are stationary (Table 4).

"The determination of optimal lag length is an important factor in implementing the model, since it can have a great influence on the results of the model" (Lojanica, 2018 , p. 23). There are several criteria of lag periods selection in the model which often do not give the same results. Lag period selection tests (Table 5) show that 1 lag period is optimal (which will be used in the research as an optimal lag period), whereas only LR test suggests 3 lag periods as an optimal choice. 
Table 3. ADF test for time series stationarity (original values)

\begin{tabular}{|c|c|c|c|c|c|c|c|c|c|c|c|c|c|c|}
\hline & \multicolumn{2}{|c|}{ CPI } & \multicolumn{2}{|c|}{ ER } & \multicolumn{2}{|c|}{ EU IR } & \multicolumn{2}{|c|}{ IP } & \multicolumn{2}{|c|}{ IR } & \multicolumn{2}{|c|}{ M1 } & \multicolumn{2}{|c|}{ OIL } \\
\hline & $\begin{array}{c}t- \\
\text { Stat }\end{array}$ & $\begin{array}{l}\text { Pro } \\
\text { b. * }\end{array}$ & $\begin{array}{c}t- \\
\text { Stat }\end{array}$ & $\begin{array}{l}\text { Pro } \\
\text { b. }{ }^{*}\end{array}$ & $\begin{array}{c}t- \\
\text { Stat }\end{array}$ & $\begin{array}{l}\text { Pro } \\
\text { b. }{ }^{*}\end{array}$ & $\begin{array}{c}t- \\
\text { Stat }\end{array}$ & $\begin{array}{l}\text { Pro } \\
\text { b.* }\end{array}$ & $\begin{array}{c}t- \\
\text { Stat }\end{array}$ & $\begin{array}{l}\text { Pro } \\
\text { b. }{ }^{*}\end{array}$ & $\begin{array}{c}t- \\
\text { Stat }\end{array}$ & $\begin{array}{l}\text { Pro } \\
\text { b. }{ }^{*}\end{array}$ & $\begin{array}{c}t- \\
\text { Stat }\end{array}$ & $\begin{array}{l}\text { Pro } \\
\text { b. }\end{array}$ \\
\hline $\begin{array}{c}\mathrm{ADF} \\
\text { test }\end{array}$ & $\begin{array}{r}- \\
11.5 \\
033\end{array}$ & $\begin{array}{r}0.0 \\
001\end{array}$ & 9.490 & 0 & $\begin{array}{r}- \\
0.95 \\
509\end{array}$ & $\begin{array}{r}0.7 \\
659\end{array}$ & $\begin{array}{r}- \\
0.30 \\
481\end{array}$ & $\begin{array}{r}0.9 \\
184\end{array}$ & $\begin{array}{r}- \\
4.42 \\
269\end{array}$ & $\begin{array}{r}0.0 \\
005\end{array}$ & $\begin{array}{r}- \\
3.39 \\
195\end{array}$ & $\begin{array}{r}0.0 \\
143\end{array}$ & $\begin{array}{r}- \\
7.60 \\
294\end{array}$ & 0 \\
\hline $1 \% *$ & $\begin{array}{r}- \\
3.50 \\
833\end{array}$ & & $\begin{array}{r}- \\
3.50 \\
833\end{array}$ & & $\begin{array}{r}- \\
3.50 \\
833\end{array}$ & & $\begin{array}{r}- \\
3.52 \\
031\end{array}$ & & $\begin{array}{r}- \\
3.50 \\
833\end{array}$ & & $\begin{array}{r}- \\
3.52 \\
031\end{array}$ & & $\begin{array}{r}- \\
3.50 \\
833\end{array}$ & \\
\hline $5 \% *$ & $\begin{array}{r}- \\
2.89 \\
551\end{array}$ & & $\begin{array}{r}- \\
2.89 \\
551\end{array}$ & & $\begin{array}{r}- \\
2.89 \\
551\end{array}$ & & $\begin{array}{r}- \\
2.90 \\
067\end{array}$ & & $\begin{array}{r}- \\
2.89 \\
551\end{array}$ & & $\begin{array}{r}- \\
2.90 \\
067\end{array}$ & & $\begin{array}{r}- \\
2.89 \\
551\end{array}$ & \\
\hline $\begin{array}{c}10 \% \\
*\end{array}$ & $\begin{array}{r}- \\
2.584 \\
95\end{array}$ & & $\begin{array}{r}- \\
2.58 \\
495\end{array}$ & & $\begin{array}{r}- \\
2.58 \\
495\end{array}$ & & $\begin{array}{r}- \\
2.58 \\
769\end{array}$ & & $\begin{array}{r}- \\
2.58 \\
495\end{array}$ & & $\begin{array}{r}- \\
2.58 \\
769\end{array}$ & & $\begin{array}{r}- \\
2.58 \\
495\end{array}$ & \\
\hline & Statio & ary & Statio & lary & $\begin{array}{r}\mathrm{No} \\
\text { statio }\end{array}$ & & $\begin{array}{r}\mathrm{Nc} \\
\text { static }\end{array}$ & & Static & Iary & Stati & lary & Stat & ary \\
\hline
\end{tabular}

Source: Authors' calculation

* Test critical values

Table 4. Time series stationarity (differentiated values) test

\begin{tabular}{|c|c|c|c|c||}
\hline \multirow{2}{*}{} & \multicolumn{2}{|c|}{ EU IR } & \multicolumn{2}{c||}{ IP } \\
\cline { 2 - 5 } & $t$-Stat & Prob. $^{*}$ & $t$-Stat & Prob. $^{*}$ \\
\hline ADF test & -8.05609 & 0 & -2.93941 & 0.0457 \\
\hline Test critical values: 1\% level & -3.50928 & & -3.52158 & \\
\hline $5 \%$ level & -2.89592 & & -2.90122 & \\
\hline $10 \%$ level & -2.58517 & & -2.58798 & \\
\hline Conclusion & \multicolumn{3}{|c|}{ Stationary } & \multicolumn{2}{c||}{ Stationary } \\
\hline
\end{tabular}

Source: Authors' calculation

Table 5. Criteria of VAR lag order selection

\begin{tabular}{||c|c|c|c|c|c|c||}
\hline \hline Lag & LogL & LR & FPE & AIC & SC & HQ \\
\hline 0 & -1645.27 & NA & $1.23 \mathrm{E}+09$ & 40.79685 & 42.27758 & 41.28633 \\
\hline 1 & -1589.2 & 101.0734 & $1.04 \mathrm{e}+09^{*}$ & $40.62216^{*}$ & $41.00377^{*}$ & $40.87987^{*}$ \\
\hline 2 & -1543.07 & 75.17604 & $1.14 \mathrm{E}+09$ & 40.693 & 43.79692 & 41.93833 \\
\hline 3 & -1493.2 & $72.64004 *$ & $1.20 \mathrm{E}+09$ & 40.67169 & 45.2241 & 42.49818 \\
\hline 4 & -1462.48 & 39.44197 & $2.15 \mathrm{E}+09$ & 41.12307 & 47.12397 & 43.53071 \\
\hline 5 & -1427.56 & 38.80958 & $3.85 \mathrm{E}+09$ & 41.47051 & 48.91991 & 44.45931 \\
\hline$*$ indicates lag order selected by the criterion \\
\hline \multicolumn{7}{|l|}{} \\
\hline
\end{tabular}

Source: Authors' calculation 
The results of the VAR analysis (Table 6) show that almost all variables are statistically significant at the level of $5 \%$ and $10 \%$, and that their impact is positive or negative. More precisely, the previous period CPI has a positive and significant impact on the current period CPI with the significance at the level of $10 \%$. Exchange rate, $\mathrm{M} 1$ and $\mathrm{EU}$ interest rate also have a positive and significant impact on CPI. The impact of industrial production is negative, whereas the impact of national interest rate is positive and significant at the level of $10 \%$. The impact of oil price shock on $\mathrm{CPI}$ is also positive and significant at the level of $10 \%$.

Table 6. VAR results

\begin{tabular}{|c|c|c|c|c|}
\hline Variables & Coefficient & Std. Error & t-Statistic & Prob. \\
\hline \multicolumn{5}{|c|}{ Dependent variable: CPI } \\
\hline CPI(-1) & 0.201142 & 0.109839 & 1.831248 & 0.0684 \\
\hline ER(-1) & 0.291868 & 0.111317 & 2.621946 & 0.0092 \\
\hline M1(-1) & 0.218636 & 0.11021 & 1.983816 & 0.0482 \\
\hline EUIR (-1) & 1.097071 & 0.116975 & 9.378679 & 0 \\
\hline $\mathrm{IP}(-1)$ & -0.01326 & 0.006186 & -2.14421 & 0.0328 \\
\hline $\operatorname{IR}(-1)$ & 3.619001 & 2.082944 & 1.737445 & 0.0833 \\
\hline OIL(-1) & 3.775741 & 2.060519 & 1.832423 & 0.0679 \\
\hline $\mathrm{C}$ & -0.39885 & 0.110147 & -3.62104 & 0.0003 \\
\hline \multicolumn{5}{|c|}{ Dependent variable: exchange rate (ER) } \\
\hline CPI(-1) & -0.00023 & 0.007137 & -0.0319 & 0.9746 \\
\hline ER(-1) & 2.123913 & 1.05695 & 2.009473 & 0.0454 \\
\hline M1(-1) & 0.032192 & 0.017971 & 1.791374 & 0.0742 \\
\hline EUIR (-1) & 0.215124 & 0.115551 & 1.861729 & 0.0636 \\
\hline $\mathrm{IP}(-1)$ & -0.23514 & 0.099508 & -2.36304 & 0.019 \\
\hline $\operatorname{IR}(-1)$ & -0.29187 & 0.105259 & -2.77285 & 0.0059 \\
\hline OIL(-1) & -0.21864 & 0.104212 & -2.09799 & 0.0367 \\
\hline $\mathrm{C}$ & -0.01326 & 0.005849 & -2.26762 & 0.0241 \\
\hline \multicolumn{5}{|c|}{$\frac{1}{\text { Dependent variable: } \text { industrial production (IP) }}$} \\
\hline CPI(-1) & 0.509357 & 0.110558 & 4.607141 & 0 \\
\hline ER(-1) & -0.49265 & 0.17849 & -2.76007 & 0.0061 \\
\hline M1(-1) & -0.44532 & 0.194904 & -2.28482 & 0.0229 \\
\hline EUIR(-1) & -0.29113 & 0.112537 & -2.58697 & 0.0101 \\
\hline $\mathrm{IP}(-1)$ & 0.210824 & 0.11145 & 1.891637 & 0.0593 \\
\hline $\operatorname{IR}(-1)$ & -0.594 & 0.197301 & -3.01063 & 0.0029 \\
\hline OIL(-1) & -0.9737 & 0.437092 & -2.22768 & 0.0265 \\
\hline $\mathrm{C}$ & 0.606354 & 0.844818 & 0.717733 & 0.4736 \\
\hline
\end{tabular}

Source: Authors' calculation 
Exchange rate VAR shows that CPI does not have a significant impact on exchange rate, whereas the impact of the previous period exchange rate on the current exchange rate movements is positive. M1 and EU interest rate also have a positive impact on exchange rate against a significance of $10 \%$. On the other hand, the impact of industrial production and national interest rate on exchange rate is negative and significant. In addition to that, raise in oil prices has an adverse effect on exchange rate.

Industrial production VAR shows that CPI has a positive impact on industrial production, whereas exchange rate has a negative impact. The greater monetary aggregate, as well as raise in EU interest rate, adversely affect industrial production, whereas an increase in industrial production in the previous period leads to an increase in industrial production in the current period. National interest rate and oil price shock have an adverse and significant impact on industrial production.

$V A R$ residual analysis shows that CPI residuals are unevenly dispersed, in particular in the last quarter of the period under observation, whereas exchange rate residuals are also unevenly distributed for the most of the period under observation. The descriptive observation shows that industrial production residuals are significantly more evenly distributed around the central tendency (Figure 2).

Figure 2. VAR residuals

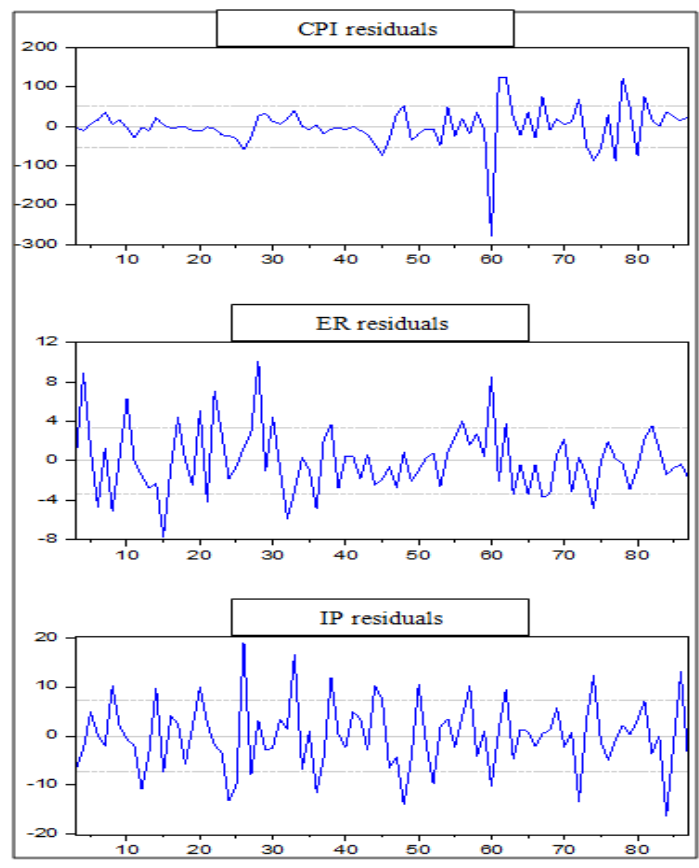

Source: Authors 
The analysis of autocorrelation functions (Figure 3) shows that residuals are independently and identically distributed as in the majority of cases the autocorrelation function is mapped within a boundary of 2 standard errors.

Figure 3. Autocorrelation function of residuals (upper and lower boundary of 2 standard errors)

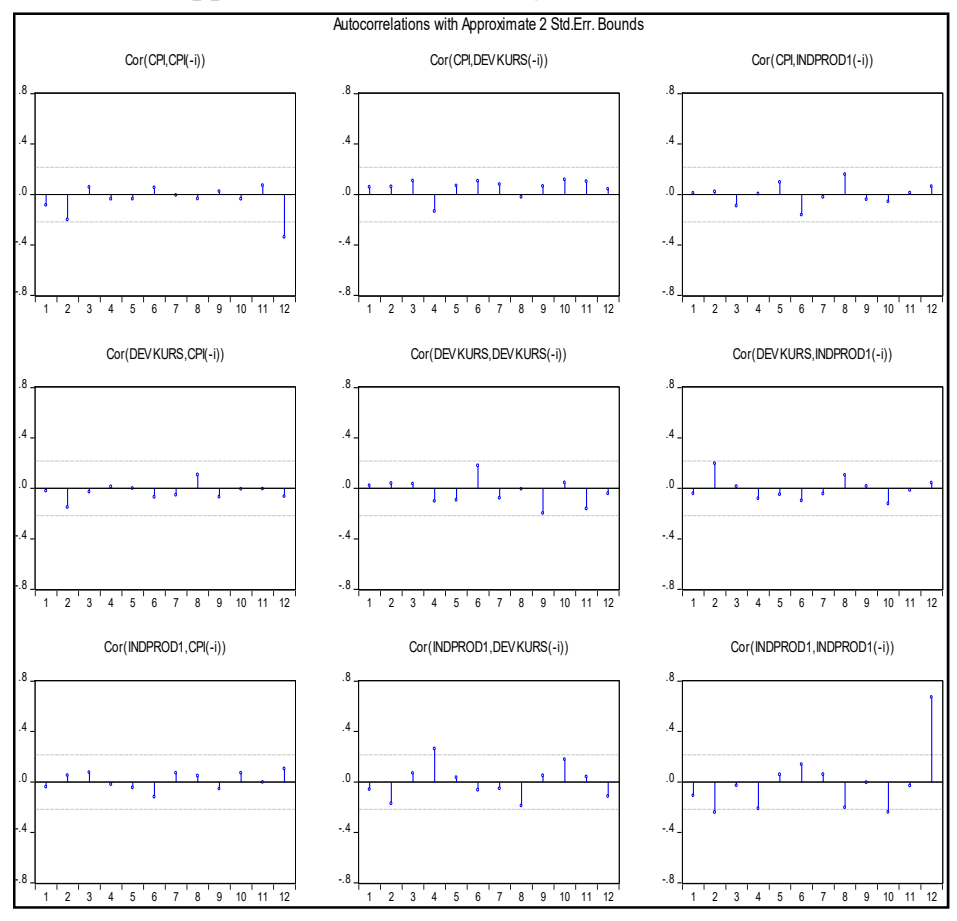

Source: Authors

The Portmanteau correlation test (Table 7) shows that the null hypothesis is accepted and that there is no residual autocorrelation within 12 lag periods. In addition to that, the residual normality test by applying Cholesky (Lutkepohl) (Table 8 ), as an orthogonalization method, shows residual multivariate normality.

Table 7. Portmanteau tests for residual autocorrelations

\begin{tabular}{|c|c|c|c|c|c||}
\hline \hline Lags & Q-Stat & Prob. & Adj. Q-stat. & Prob. & Df* \\
\hline 1 & 2.653466 & 0.9765 & 2.685055 & 0.9755 & 9 \\
\hline 2 & 20.47874 & 0.3065 & 20.93985 & 0.2825 & 18 \\
\hline 3 & 23.81494 & 0.6406 & 24.39811 & 0.6082 & 27 \\
\hline 4 & 37.22169 & 0.4126 & 38.46692 & 0.3585 & 36 \\
\hline
\end{tabular}


Obradović, Đorđević / Economic Themes, 58(1): 53-73

\begin{tabular}{|c|c|c|c|c|c||}
\hline \hline 5 & 39.76085 & 0.6929 & 41.16478 & 0.6351 & 45 \\
\hline 6 & 51.44193 & 0.5737 & 53.73303 & 0.4846 & 54 \\
\hline 7 & 53.84464 & 0.7878 & 56.35137 & 0.7104 & 63 \\
\hline 8 & 65.32204 & 0.698 & 69.02123 & 0.5777 & 72 \\
\hline 9 & 70.20285 & 0.7985 & 74.48002 & 0.6822 & 81 \\
\hline 10 & 81.63596 & 0.7237 & 87.43755 & 0.5569 & 90 \\
\hline 11 & 85.34432 & 0.8342 & 91.69715 & 0.686 & 99 \\
\hline 12 & 136.7764 & 0.0321 & 151.5838 & 0.1036 & 108 \\
\hline \multicolumn{7}{|l||}{ Null Hypothesis: no residual autocorrelations up to lag $h$} \\
\hline$*$ Df is degrees of freedom for (approximate) chi-square distribution \\
\hline * The test is valid only for lags larger than the VAR lag order \\
\hline \hline
\end{tabular}

Source: Authors' calculation

Table 8. Residual normality tests

\begin{tabular}{|c|c|c|c|c|}
\hline Component & Skewness & Chi-sq & df & Prob. \\
\hline 1 & -0.16348 & 0.378634 & 1 & 0.5383 \\
\hline 2 & -0.00873 & 0.001079 & 1 & 0.9738 \\
\hline 3 & -0.1203 & 0.20502 & 1 & 0.6507 \\
\hline 4 & -0.19456 & 0.536249 & 1 & 0.464 \\
\hline 5 & -0.01045 & 0.001547 & 1 & 0.9686 \\
\hline Joint & & 1.122529 & 5 & 0.9521 \\
\hline Component & Kurtosis & Chi-sq & $\mathrm{df}$ & Prob. \\
\hline 1 & 3.020999 & 0.001562 & 1 & 0.9685 \\
\hline 2 & 2.318557 & 1.644626 & 1 & 0.1997 \\
\hline 3 & 3.685959 & 1.666496 & 1 & 0.1967 \\
\hline 4 & 3.366477 & 0.475664 & 1 & 0.4904 \\
\hline 5 & 3.196578 & 0.13686 & 1 & 0.7114 \\
\hline Joint & & 3.925208 & 5 & 0.5602 \\
\hline Component & Jarque-Bera test & $\mathrm{df}$ & Prob. & ------------------- \\
\hline 1 & 0.380196 & 2 & 0.8269 & ------------------- \\
\hline 2 & 1.645705 & 2 & 0.4392 & ----------------" \\
\hline 3 & 1.871517 & 2 & 0.3923 & ------------------- \\
\hline 4 & 1.011913 & 2 & 0.6029 & |------------------ \\
\hline 5 & 0.138407 & 2 & 0.9331 & ------------------ \\
\hline Joint & 5.047738 & 10 & 0.888 & ---------------- \\
\hline \multicolumn{5}{|c|}{ Null Hypothesis: Residuals are multivariate normally distributed } \\
\hline \multicolumn{5}{|c|}{ Orthogonalization: Cholesky (Lutkepohl) } \\
\hline
\end{tabular}

Source: Authors' calculation 
The following tables show variance decomposition of CPI, exchange rate and industrial production, respectively. Variance decomposition of CPI (Table 9) shows that $95.21 \%$ of the CPI variations are explained by the variations of the very CPI, whereas $1.39 \%$ of the CPI variations are explained by the shifts in national interest rate. Besides, oil price variations explain $1.22 \%$ of CPI variations, whereas the impact of other variables is minor.

Table 9. Variance decomposition of CPI

\begin{tabular}{||c|c|c|c|c|c|c|c|c||}
\hline Period & Std.errors & CPI & ER & EU IR & IP & IR & M1 & OIL \\
\hline 1 & 52.44801 & 100 & 0 & 0 & 0 & 0 & 0 & 0 \\
\hline 2 & 54.98721 & 96.19286 & 0.624781 & 0.010756 & 0.724894 & 1.014905 & 0.238658 & 1.193146 \\
\hline 4 & 55.28832 & 95.27244 & 0.671118 & 0.091076 & 0.743349 & 1.347954 & 0.66374 & 1.210319 \\
\hline 6 & 55.30482 & 95.21582 & 0.672988 & 0.092112 & 0.744833 & 1.387088 & 0.67074 & 1.216417 \\
\hline 8 & 55.3066 & 95.20972 & 0.673371 & 0.092176 & 0.744896 & 1.391884 & 0.670747 & 1.21721 \\
\hline 10 & 55.30684 & 95.2089 & 0.673437 & 0.092187 & 0.744895 & 1.392529 & 0.670746 & 1.217309 \\
\hline \multicolumn{7}{|c|}{ Method: 0 Carlo (10000 repetitions) } \\
\hline
\end{tabular}

Source: Authors' calculation

Variance decomposition of exchange rate (Table 10) shows that $88.93 \%$ of exchange rate variations are explained by the very exchange rate variations, whereas $5.70 \%$ of variations of exchange rate are explained by national interest rate variations. That indicates that national interest rate could be a significant intermediary target of monetary policy if exchange rate control would be its primary goal. It is important to note that $2.59 \%$ of exchange rate variations are explained by industrial production variations, whereas $1.80 \%$ of exchange rate variations are explained by CIP changes.

Table 10. Variance decomposition of exchange rate

\begin{tabular}{||c|c|c|c|c|c|c|c|c||}
\hline \hline Period & Std.errors & CPI & ER & EU IR & IP & IR & M1 & OIL \\
\hline 1 & 3.408108 & 1.886619 & 98.11338 & 0 & 0 & 0 & 0 & 0 \\
\hline 2 & 3.543592 & 1.817569 & 91.36391 & 0.121411 & 2.522602 & 3.8111 & 0.196413 & 0.166994 \\
\hline 4 & 3.587872 & 1.805738 & 89.23311 & 0.161953 & 2.596783 & 5.435819 & 0.283186 & 0.483416 \\
\hline 6 & 3.593883 & 1.800677 & 88.96867 & 0.169357 & 2.58966 & 5.667422 & 0.283167 & 0.521051 \\
\hline 8 & 3.594682 & 1.800153 & 88.93268 & 0.169764 & 2.588685 & 5.698975 & 0.283473 & 0.526267 \\
\hline 10 & 3.594787 & 1.800086 & 88.92794 & 0.169815 & 2.588569 & 5.703111 & 0.28351 & 0.526972 \\
\hline \multicolumn{10}{|l|}{ Method: Monte Carlo (10000 repetitions) } \\
\hline \multicolumn{10}{|l|}{}
\end{tabular}

Source: Authors' calculation 
Variance decomposition of industrial production (Table 11) shows that $85.37 \%$ of industrial production variations are explained by changes in industrial production, whereas $9.03 \%$ industrial production variations are explained by changes in M1. That indicates that a change in monetary aggregate has a strong impact on the real sector of economy. Having in mind a pronounced currency substitution in Serbia, it is not surprising that $2.95 \%$ of industrial production variations are explained by the EU interest rate variations.

Table 11. Variance decomposition of industrial production

\begin{tabular}{||c|c|c|c|c|c|c|c|c||}
\hline \hline Period & Std.errors & CPI & ER & EU IR & IP & IR & M1 & OIL \\
\hline 1 & 0.220923 & 0.112116 & 0.056397 & 1.96548 & 97.86601 & 0 & 0 & 0 \\
\hline 2 & 0.230858 & 0.897671 & 0.293195 & 2.401175 & 87.41293 & 0.596975 & 7.947271 & 0.450786 \\
\hline 4 & 0.232642 & 1.016681 & 0.533847 & 2.947833 & 85.37679 & 0.636278 & 9.03328 & 0.455294 \\
\hline 6 & 0.232751 & 1.016639 & 0.535785 & 2.947884 & 85.37444 & 0.636636 & 9.032984 & 0.45563 \\
\hline 8 & 0.232765 & 1.016657 & 0.535811 & 2.947932 & 85.37418 & 0.636662 & 9.033129 & 0.45563 \\
\hline 10 & 0.232767 & 1.016657 & 0.535811 & 2.947932 & 85.37418 & 0.636663 & 9.033129 & 0.45563 \\
\hline \multicolumn{7}{|c|}{ Method: Monte Carlo (10000 repetitions) } \\
\hline \multicolumn{10}{|l}{}
\end{tabular}

Source: Authors' calculation

Figure 4. Impulse response functions (CPI)

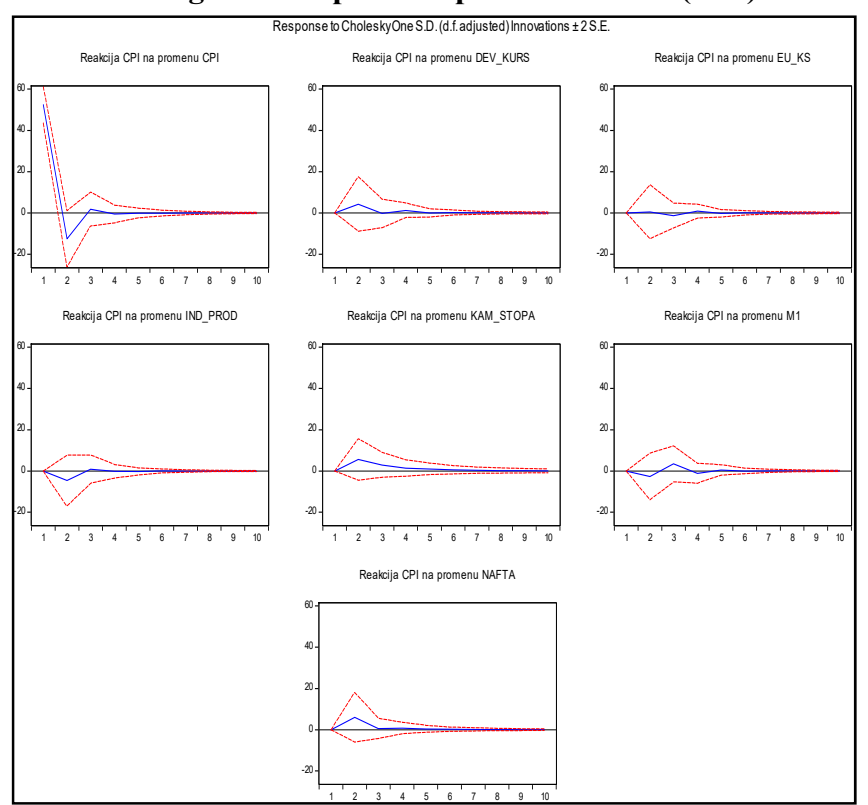

Source: Authors 
The analysis of the impulse response function (Figure 4) shows that an inflationary shock triggers a prompt positive CPI response which transforms into its negative value at the end of month two, while the effects are neutralized after four and a half months. Change in exchange rate causes a mild positive CPI response in the period from month one to month four. Change in EU interest rate has a minor negative effect on CPI which oscillates around the central tendency (almost a neutral effect). Growth in industrial production causes CPI reduction in the period from month one to month six, while growth in national interest rate causes growth in CPI against effects lasting from month one to month six. Such effect of interest rate raise is contrary to economic theory postulates. Increase in M1 initially affects CPI reduction in the period of one to two and a half months, whereas in the subsequent month monetary aggregate increase has an inflationary effect. After six months the effects of the increase of monetary aggregate on CPI are neutralized. Oil price shock causes a prompt CPI increase in the period from month one to month six, which is in accordance with the assumptions of the theory of imported inflation.

Figure 5. Impulse response functions (exchange rate)

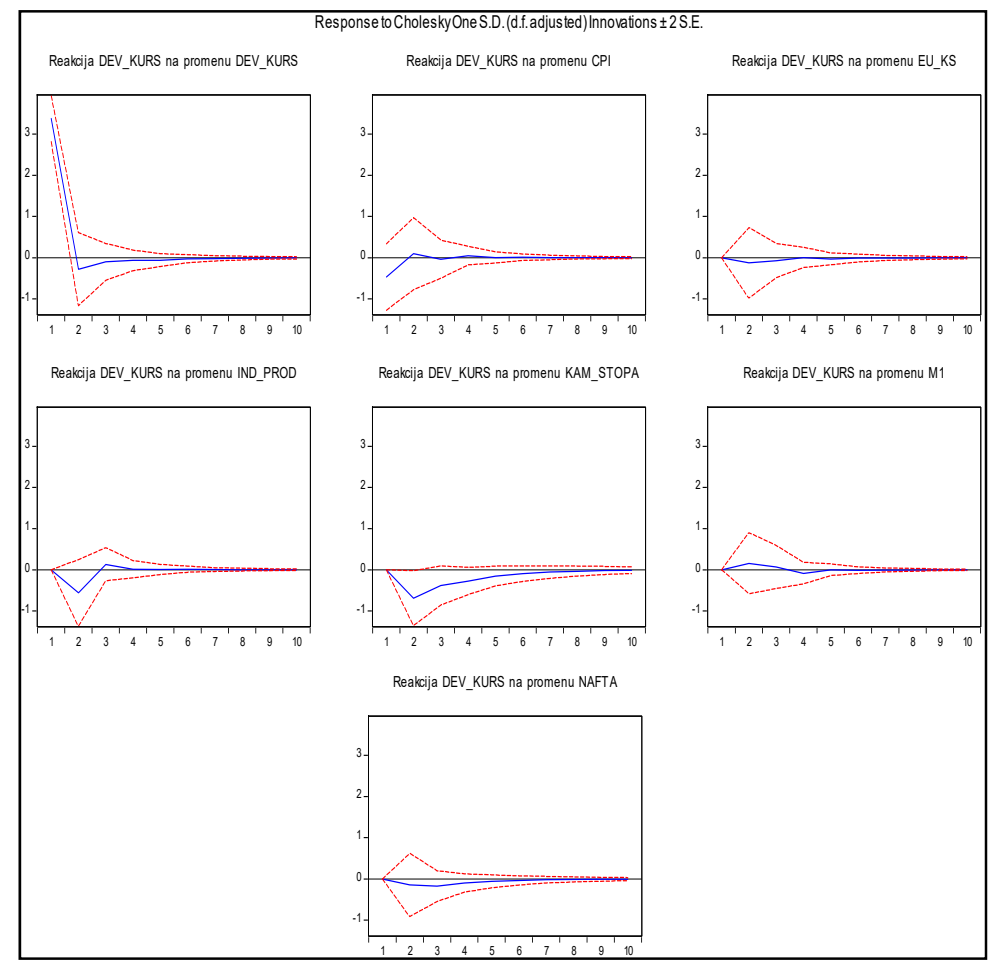

Source: Authors 
Exchange rate appreciation (Figure 5) has a positive prompt effect on exchange rate, while the effect assumes negative values from month two to month seven. Increase in CPI has an initial negative effect on exchange rate, which is in accordance with the assumptions of the monetary theory. In the period from month two to month eight a minor positive effect is recorded. Increase in the $\mathrm{EU}$ interest rate has a minor negative effect in the period from month one to month seven, while after that period the effect is neutralized. Growth in industrial production causes a prompt depreciation of exchange rate in the period from month one to month three, against a mild appreciation from month three to month eight. Raise in national interest rate affects an initially steep and long-standing depreciation of exchange rate which is contrary to the assumptions of the monetary theory. However, having in mind a high currency substitution, it is possible to treat the raise in national interest rate as a signal of increased risks to which the foreign exchange market responds with additional conversions into euro. Increase in M1 has an impact on a mild appreciation of exchange rate in the period from month one to three and a half months and following that the effect is almost neutral. Oil price shock causes a minimal negative response of exchange rate in the period from month one to month six.

Figure 6. Impulse response functions (industrial production)

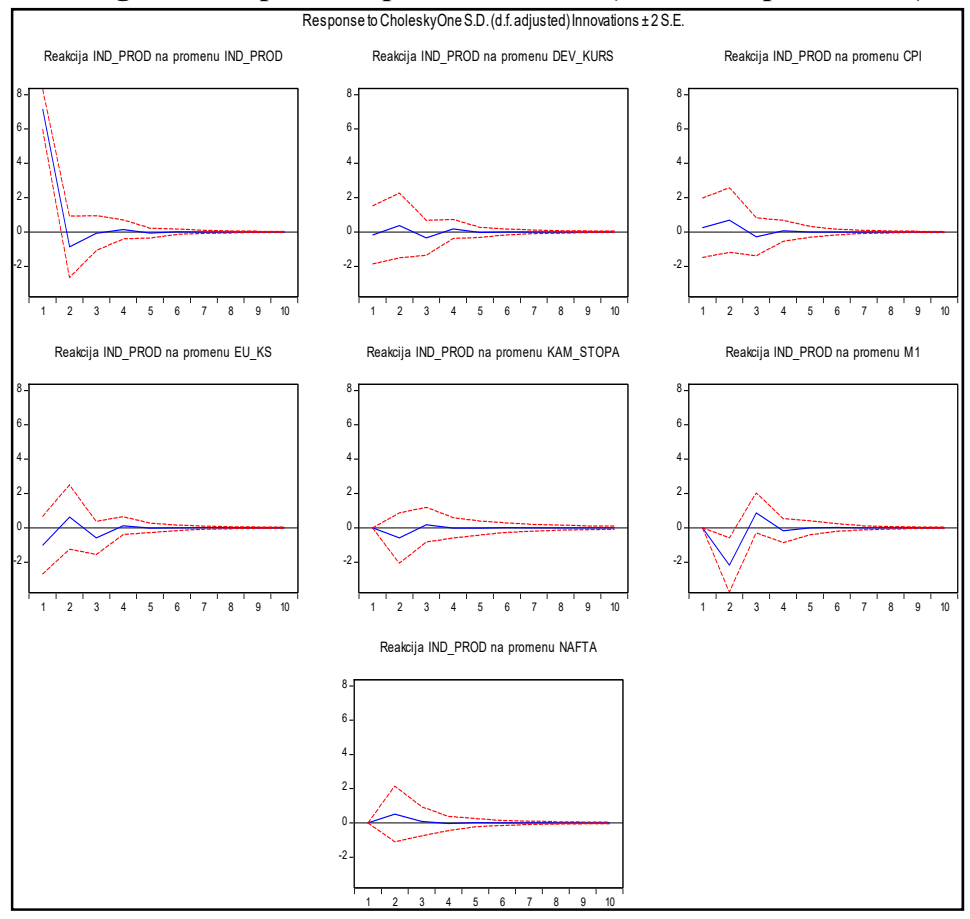

Source: Authors 
Growth of industrial production results in a prompt increase in industrial production in the first period, however against a steep fall tendency (Figure 6). The impact is negative between months two and four and the overall effect is exhausted after six and a half months. Appreciation of exchange rate has a minimal adverse effect in the first month, a somewhat greater positive effect after two and a half months and again a negative effect in the period of up to three and a half months. Increase in CPI has an impact on an initial growth in industrial production in the period of one up to two and a half months and in the following two months the inflationary effect on industrial production is negative. That effect is fully exhausted after six months. A raise in the EU interest rate causes reduction in industrial production in the period of one and a half month, whereas the effect is positive in the following month. Following that, there is a short-term reduction in industrial production with the effect fully exhausted after six and a half months. The raise in national interest rate causes a fall in industrial production in the period between month one and month three, coupled with a minor positive effect in the following one month period. Following that the effect is negative.

Increase in monetary aggregate causes a reduction in industrial production in the period of one to two and a half months, while in the period of a month and a half after that the effect is positive. After five months the effect of change in monetary aggregate on industrial production is neutral. Oil price shock has a positive effect on industrial production in the period of one to three and a half months and by the end of the period under consideration the effect is neutral.

\section{Conclusion}

One of the primary functions of central banks is pursuance of monetary policy. In modern times, the primary goal of monetary policy is to achieve price stability, as well as to fuel economic growth. The transmission mechanism of monetary policy implies the impact of monetary impulses on price level and real economic parameteres and it is an object of research in a great number of scientific papers. Monetary impulses are transmitted through a few channels of monetary transmission, whereby the prevalence of certain channels in each country depends on a great number of factors.

In order to conduct an empirical analysis of the impact of monetary policy on real economic trends in Serbia, the Vector autoregression model (VAR model) was used, just as it was used in a great number of papers dealing with this matter, both in the developed and developing countries. The analysis comprises monthly data from January 2010 through April 2017.

The matrix of correlation of macroeconomic variables shows that in Serbia there is a stronger positive correlation between industrial production and M1. This is confirmed both by the results of variance decomposition and impulse response 
function. Variance decomposition of industrial production shows that variations of industrial production (except in previous variations of industrial production itself) are predominantly explained by changes in M1, which indicates that a change in monetary aggregates has a strong impact on the real sector of economy in Serbia. In addition to that, variations of industrial production are also explained by the EU interest rate variations, which is not surprising given a pronounced currency substitution in Serbia.

Variance decomposition of exchange rate shows that exchange rate variations, in the period under observation, are to a certain degree (more significant than other variables) explained by changes in national interest rate. That indicates that the national interest rate may be an important intermediary target of monetary policy, if the exchange rate control would be its primary goal. The same result is obtained with the variance decomposition of CPI, giving hints of the existence of the interest rate channel in Serbia (in the period under consideration) and possibilities of action of monetary authorities aimed at fostering this channel of monetary transmission in Serbia.

\section{References}

Anant, S. P. \& Kaur, S. D. (2017). Transmission Mechanism of Monetary Policy: Case Study of Interest Rate Channel in India. Journal of Indian Economy, 4 (2), doi: 10.17492/pragati.v4i02.11465

Angeloni, I., Kashyap, A., Mojon, B. \& Terlizzese, D. (2002). Monetary Transmission in the Euro Area: Where Do We Stand? (Working Paper, No. 114), European Central Bank.

Arestis, P. \& Sawyer, M. C. (2002). Can monetary policy affect the real economy? (Working Paper, No. 355), NY: Levy Economics Institute of Bard College.

Bernanke, B., Boivin, J. \& Eliasz, P. (2004). Measuring the effects of monetary policy: a factoraugmented vector autoregressive (FAVAR) approach (Working Paper, No.10220), Cambridge: National Bureau of Economic Research.

Bernanke, B. \& Gertler, M. (1995). Inside the Black Box: The Credit Channel of Monetary Policy Transmission. Journal of Economic Perspectives, 9 (4), 27-48.

Bernanke, B. \& Mihov, I. (1995). Measuring monetary policy (Working Paper, No.5145), Cambridge: National Bureau of Economic Research.

Barran, F., Coudert, V. \& Mojon, B. (1996). The transmission of monetary policy in the European countries (Document de travail, 96(03)), CEPII.

Berument, H. \& Dincer, N. N. (2008). Measuring the effects of monetary policy for Turkey. Journal of Economic Cooperation, 29(1), 83-110.

Bjørnland, H. C. (2008). Monetary policy and exchange rate interactions in a small open economy. The Scandinavian Journal of Economics, 110 (1), 197-221.

Bungin, S. (2016). Deset godina ciljanja inflacije u Srbiji. Bankarstvo, 45 (2), 140-157, doi: 10.5937/bankarstvo1702140B

Dabla-Norris, E. \& Floerkemeier, H. (2006). Transmission mechanisms of monetary policy in Armenia: evidence from VAR analysis (IMF Working Paper, WP/06/248), International Monetary Fund.

Đorđević, M. (2005). Realni efekti monetarne politike. Bankarstvo, 7-8, 8-17. 
Jarociński, M. (2008). Responses to Monetary Policy Shocks in the East and the West of Europe (Working Paper Series, No. 970), European Central Bank.

Lojanica, N. (2018). Makroekonomski efekti monetarne transmisije u Srbiji: SVAR pristup. Bankarstvo, 47 (1), 14-31, doi: 10.5937/bankarstvo1801014L

Mojon, B. \& Peersman, G. (2001). A VAR description of the effects of monetary policy in the individual countries of the euro area (Working Paper, No.92), European Central Bank.

Peersman, G. \& Smets, F. (2001). The monetary transmission mechanism in the euro area: more evidence from VAR analysis (Working Paper, No.91), European Central Bank.

Robinson, W. \& Robinson, J. W. (1997). The transmission mechanism of monetary policy in the Jamaican economy. Annual Conference of the Caribbean Centre for Monetary Studies.

Sims, C. A. (1980). Macroeconomics and Reality. Econometrica, 48, 1-48.

Taylor, J. B. (1995). The Monetary Transmission Mechanism: An Empirical Framework. Journal of Economic Perspectives, 9 (4), 11-26.

Van Els, P., Locarno, A., Morgan, J. \& Villetelle J. P. (2001). Monetary Policy Transmission in the Euro Area: What Do Aggregate and National Structural Models Tell Us? (Working Paper, No. 94), European Central Bank.

Vizek, M. (2007). Ekonometrijska analiza kanala monetarnog prijenosa u Hrvatskoj. Privredna kretanja i ekonomska politika, 16 (109), 28-61.

Yushina, V. A. (2019). An econometric study of interest rate channel in Russia. Экономика и бизнес: теория и практика, doi: 10.24411/2411-0450-2019-10749

Žigman, A. \& Lovrinčević, Ž. (2005). Monetarna politika ciljane inflacije i transmisijski mehanizam - iskustva za Hrvatsku. Ekonomski pogledi, 56 (7-8), 433-457.

\section{TRANSMISIJA MONETARNE POLITIKE NA REALNA KRETANJA U SRBIJI - VAR ANALIZA}

Apstrakt: Efikasnost kanala monetarne transmisije se razlikuje između zemalja, a uslovljena je nizom faktora koji karakterišu privredni i finansijski sistem zemlje. Kako bi se postigli postavljeni ciljevi monetarne politike, centralna banka preduzima određene mere i koristi instrumente monetarne politike. Međutim, ovi instrumenti deluju indirektno i sa određenim vremenskim kašnjenjem. Upravo zbog ovih ograničenja u delovanju monetarne politike bitna je analiza monetarne transmisije u svakoj zemlji, kako bi kreatori odredili optimalni monetarni režim. U ovom radu, uz pomoć modela vektorske autoregresije (VAR model), izvršena je analiza monetarne transmisije $u$ Republici Srbiji. Značaj sprovedenog istraživanja ogleda se u aktuelnosti problema uticaja monetarne politike na realna ekonomska kretanja, kako u razvijenim, tako i u zemljama u razvoju. Na osnovu ovog istraživanja zaključili smo da, u posmatranom vremenskom periodu, na fluktuacije industrijske proizvodnje u Srbiji najviše utiče novčana masa, a na fluktuacije cena kretanje referentne kamatne stope. Rezultati analize daju smernice u preduzimanju neophodnih koraka monetarnim vlastima, kako bi uticali na smanjenje vremenskog zaostatka i eliminisanje ograničenja u prenosu monetarnih impulsa na realne ekonomske veličine.

Ključne reči: transmisija monetarne politike, kamatna stopa, CPI, devizni kurs, industrijska proizvodnja, M1, cena nafte, VAR model 


\section{Authors' biographies}

Jelena Obradović is a teaching assistant at Novi Sad School of Business and a $\mathrm{PhD}$ student at the Faculty of Economics, University of Niš. She obtained her bachelor's degree and master's degree from the Faculty of Economics Subotica, University of Novi Sad (Department of Finance, banking and insurance) in 2008 and 2010, respectively. She has published several scientific papers and has participated in several national and international conferences.

Marina Đorđević is a full professor at the Faculty of Economics, University of Niš. She teaches Monetary and Public Finance. She earned her master's degree and doctorate degree from the Faculty of Economics in Niš in 2002 and 2009, respectively. She has published a number of papers in scientific journals and has participated in national and international conferences in the country and abroad. She has participated in projects of the Faculty of Economics in Niš and the Ministry of Science, Republic of Serbia. 